\title{
New feather mite species of the family Pteronyssidae (Astigmata: Analgoidea) from South African passerines (Aves: Passeriformes)
}

\author{
Sergei V. Mironov ${ }^{1}$ and Grzegorz Kopij ${ }^{2}$ \\ ${ }^{1}$ Zoological Institute, Russian Academy of Sciences, Universitetskaya Emb. 1, 199034, Saint Petersburg, Russia; \\ ${ }^{2}$ Department of Biology, National University of Lesotho, P.O. Roma 180, Lesotho
}

Key words: Acari, Analgoidea, Avenzoariidae, Pteronyssinae, new species, Passeriformes, South Africa

\begin{abstract}
Four new species of feather mites belonging to three different genera of the family Pteronyssidae are described from passerine birds of South Africa: Pteroherpus africanus sp. n. from the garden bulbul Pycnonotus barbatus (Desfontaines) (Pycnonotidae), Pteroherpus cysticolae sp. n. from the wing-snapped cisticola Cisticola ayresii Hartlaub (Sylviidae), Pteronyssoides promeropis sp. n. from the Gurney's sugarbird Promerops gurneyi Verreaux (Promeropidae), and Sturnotrogus creatophorae sp. $\mathrm{n}$. from the wattled starling Creatophora cinerea Menschen (Sturnidae). A brief review of recent publications on the taxonomy of the family Pteronyssidae is given.
\end{abstract}

The present paper continues the series of our publications dedicated to feather mites associated with South African passerines (Mironov and Kopij 1966a, b, 1997, 2000) and includes descriptions of four new feather mite species of the family Pteronyssidae Oudemans, 1941. The family Pteronyssidae currently includes 18 genera and about 130 described species. The representatives of this family are mostly associated with different bird families of Piciformes and Passeriformes and only one genus, Cleyastobius Gaud, 1981, occurs on the wooden hoopoes Phoeniculidae (Coraciiformes). A detailed generic revision of the family Pteronyssidae (considered in a status of subfamily) was carried out by Faccini and Atyeo (1981). A review of species associated with birds of the orders Piciformes and Passeriformes in Europe and Northern Asia was given by Mironov (1989). Several new species were recorded from birds of South East Asia (Gaud and Petitot 1948, Gaud and Corpuz-Raros 1985, Mironov 1992, 1993). Atyeo and co-authors (Atyeo et al. 1987) reviewed the species associated with the Neotropical Piciformes. Gaud and Mouchet (1959) described a vast number of new species from Central Africa, and lately Gaud has published a series of reviews on the pteronyssid genera restricted to Piciformes in Africa (Gaud 1988, 1989, 1990a, b, 1991). Finally, Gaud and Atyeo (1996) have proposed a key to all recent genera of the family.

\section{MATERIALS AND METHODS}

The materials used in the present study were received from the mite collection of the National Museum of Bloemfontein (Free State, Republic of South Africa). Descriptions of new species are given in a standard format used for respective genera of the Pteronyssidae (Faccini and Atyeo 1981, Mironov 1992). Idiosomal chaetotaxy follows Griffiths et al.
(1990); leg chaetotaxy is that of Atyeo and Gaud (1966). Terms used for the set of dorsal hysteronotal shields in females of the genus Pteroherpus were proposed by Mironov (1992). All measurements are given in micrometres. As the number of specimens in the type series was rather restricted, we give the full set of measurements only for the holotype (male) and for one paratype (female). The range of idiosomal size (length, width) is displayed for other paratypes. Scientific names of birds follow the world checklist of Howard and Moore (1991).

The type specimens are deposited in NMB - the National Museum of Bloemfontein (Free State, Republic of South Africa), ZISP - Zoological Institute, Russian Academy of Sciences (Saint Petersburg, Russia) and PAU - the Institute of Parasitology, Academy of Sciences of the Czech Republic, (České Budějovice, Czech Republic).

\section{DESCRIPTION OF NEW TAXA}

\section{Genus Pteroherpus Gaud, 1981}

Up to date, the genus Pteroherpus has included 17 species (Mironov 1992). These mites are associated with birds of different passerine families distributed in the Old World (Dicruridae, Muscicapidae, Paradisaeidae, Pycnonotidae, Sylviidae, Timaliidae). Based on the structure of opisthosoma in males, Faccini and Atyeo (1981) recognised three species groups within the genus, benoiti, holoplax and monacrotrichus. Apparently, these groups should be designated as subgenera, but this is a task for a separate taxonomic study.

\section{Pteroherpus africanus sp. n.}

Figs. 1, 2 a,b

Male (holotype). Length of idiosoma 371, width of idiosoma 176, length of hysterosoma 210 (idiosomal size of paratype: length $366 \times 163)$. Prodorsal shield: length 113 , width 84 , distance between bases of setae se 
66, posterior margin slightly convex, lateral margins with little incision posterior to bases of setae se. Setae c2 hair-like, 15-18 in length, situated in anterior angles of humeral shields. Setae $c 3$ lanceolate with acute apex, 36 in length, 5 in width. Hysteronotal shield: anterior margin slightly sinuous, anterior angles short acute, length 187, width at anterior margin 86 , dorsal setae $e 1$ situated posterior to level of opisthonotal gland openings $g l$ (Fig. 1a). Distance between prodorsal and hysteronotal shields along medial line 65 . Opisthosomal lobes short, bluntly rounded, with narrow terminal membrane along all margin of lobe. Terminal cleft small, U-shaped, length of cleft 24, width about 7.5, margins of membranes in cleft almost contiguous. Transventral sclerite Y-shaped, length along median line 33. Epiandrium short, not encompassing genital apparatus, tips of epiandrium extending to genital arch apex only (in some paratypes these tips almost reduced) (Fig. 1b). Genital apparatus 24 in length, 26 in width. Transanal sclerite absent, adanal shield represented by pair of irregular, weakly sclerotised plates situated anterior to setae ps3. Diameter of anal discs 18 . Measurements (distances between setal bases and openings): d2:e2 84, d2:gl 26, gl:e1 14-16, h3:h3 36. Tarsus III with two apical teeth, all setae hair-like, seta $r$ slightly shorter than this segment (Fig. 1c).

Female (paratype). Length of idiosoma 430, width of idiosoma 220, length of hysterosoma 283 (idiosomal size in other paratypes: length 440-480, width 180-210). Prodorsal shield as in male, length 115, width 96, distance between setae se 72 . Setae $c 2$ short hair-like, 18-20 in length, situated on striated tegument. Setae $c 3$ lanceolate, with acute apex, $34 \times 7.2$. Arrangement of hysteronotal shields: pair of anterior hysteronotal shields, central shield, pair of lateral opisthosomal shields, and pair of pygidial shields (Fig. 2a). Anterior hysteronotal shields represented by irregular plates posterior to setae $c 2$ (in some specimens these sclerites are greatly reduced). Central shield with straight anterior margin and ovoid posterior end, 60 in length, 45 in width. Distance between prodorsal and central shields 38. Lateral opisthosomal shields represented by irregu-lar, well-sclerotised plates, with sparse longitudinal striation. Opening $g l$ situated in anterior margins of these shields. Setae $e 1$ positioned on striated tegument, approximately at level of posterior end of central shield, setae $e 2$ on lateral opisthosomal shields, setae $f 2$ on striated tegument. Measurements: $d 1: d 233$, d2:e2 113, d2:gl 93, gl:e1 21, h3:h3 55. Epigynium 46 in length, 65 in width, with short spine-like lateral processes, posterior tips slightly divergent, not fused with epimerites IIIa (Fig. 2b).
Diagnosis. Pteroherpus africanus belongs to the hoplophorus species group recently comprising 13 species (Gaud 1952, Gaud and Mouchet 1959, Mironov 1989, 1992). Males of this group are characterised by short, bluntly rounded opisthosomal lobes, closed coxal fields III, and transanal sclerite absent (Faccini and Atyeo 1981). The new species is related to the series of species: P. doleoplax (Gaud et Mouchet, 1959), $P$. hoplophorus (Gaud, 1952), P. megathyrus (Gaud et Mouchet, 1959), P. pycnonoti Mironov, 1992, $P$. krivolutskii Mironov, 1992 and P. zosteropis Mironov, 1992. Four species are associated with Pycnonotidae, while two latter species occur on Timaliidae and Zosteropidae respectively. The new species is most similar to $P$. krivolutskii by having the similar arrangement and shape of dorsal hysteronotal shields in females.

The males of $P$. africanus differ from $P$. krivolutskii by short tips of epiandrium extending to genital arch apex and by the adanal shield separated into two pieces (Fig. 1b). In males of $P$. krivolutskii, the adanal shield is represented by single T-shaped sclerite; the tips of epiandrium extend to the level of the anterior genital discs or to the midlevel of genital apparatus. In other related species listed above the epiandrium is longer and extends to the level of setae $4 a$ or genital arch basis. The adanal shield in these species is an entire plate or absent.

The females of the new species are distinguished from those of $P$. krivolutskii by having the opisthosomal shields in a form of entire irregular plates and by smaller anterior hysteronotal shields not including the bases of setae $c 2$. In females of $P$. krivolutskii the opisthosomal shields are U-shaped or each shield is completely split into two fragments (external and internal), and the anterior hysteronotal shields include the bases of setae $c 2$. It is worth to note that the general structure of lateral opisthosomal shields (form and type of striation) in P. africanus is more similar to that in other Pteroherpus species associated with the bulbuls, Pycnonotidae ( $P$. hoplophorus, $P$. megathyrus, $P$. pycnonoti). However, in females of these three species, the opisthosomal shields are fused with the central hysteronotal shield.

$\mathrm{T}$ y $\mathrm{p}$ e h o s t : Garden bulbul Pycnonotus barbatus (Desfontaines, 1787) (Pycnonotidae).

T y p e 1 o c a 1 i t y : South Africa, Free State, Pafuri.

D a t e of c o lle c ti o n : 12.01.1989, R.A. Earle coll.

$\mathrm{T}$ y p e m a t e r i a 1 : Holotype male. Paratypes: 1 male, 4 females.

D e p o s it i o n of mate ria 1: Holotype male and paratype 3 females (No. 00199) - NMB; paratypes, 1 male and 1 female (PAU AVČR No. 1976) - PAU.

A d d it i o n a $1 \mathrm{~m}$ a te $\mathrm{r}$ i a $1: 2$ males, 2 females from the red-eyed bulbul Pycnonotus nigricans (Vieillot, 1818), South Africa, Free State, Pelissier, 20.05.1989, R.A. Earle coll. 


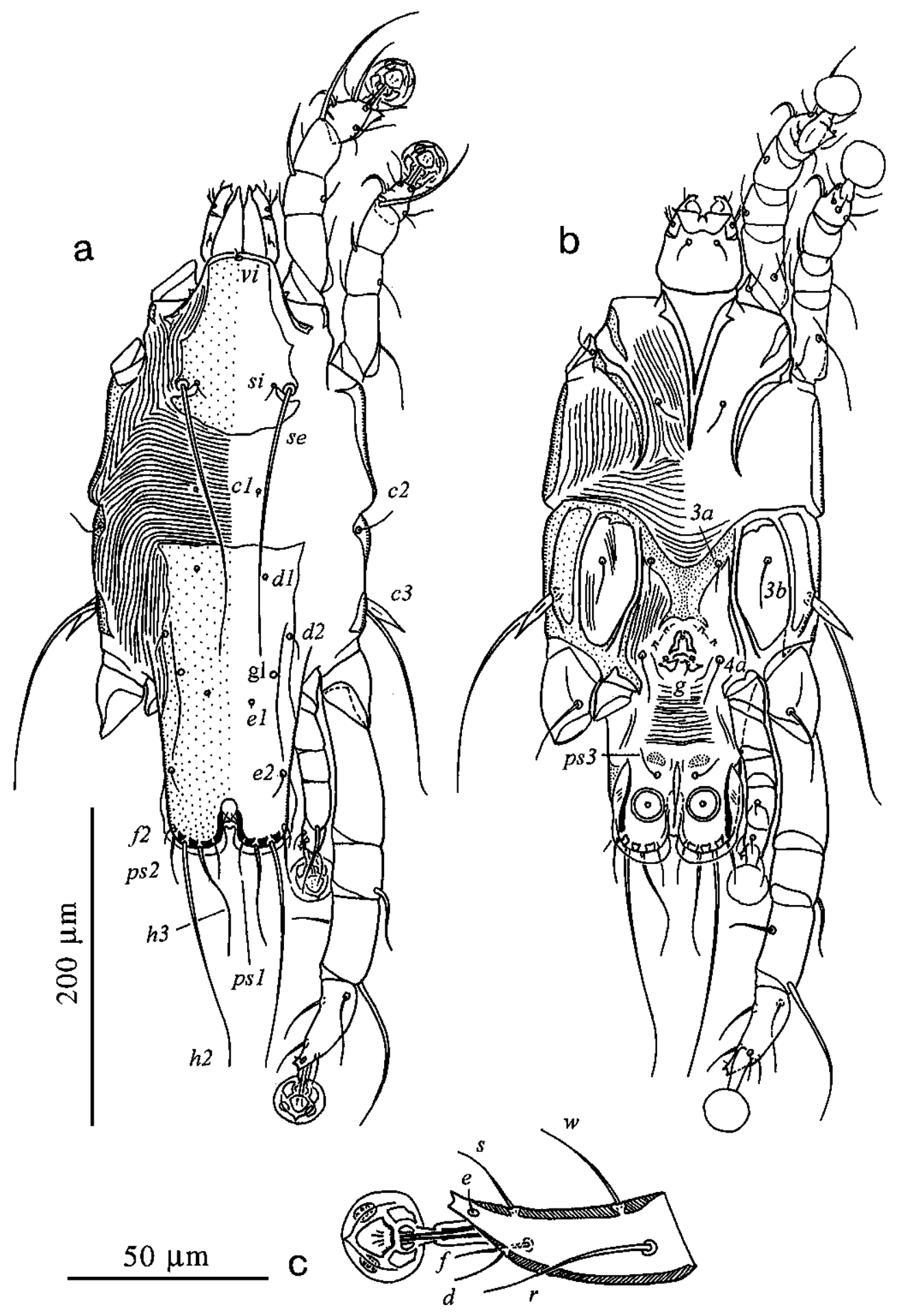

Fig. 1. Pteroherpus africanus sp. n., male. a-dorsal view; b - ventral view; c - tarsus III, dorsal view. 


\section{Pteroherpus cisticolae sp. n.}

Figs. 2 c,d; 3 a-d

Male (holotype). Length of idiosoma 322, width of idiosoma 127, length of hysterosoma 177 (idiosomal size in 5 paratypes: length 315-330, width 115-127). Prodorsal shield: length 80 , width 61 , distance between bases of setae se 53, posterior margin slightly convex, lateral margins without incision posterior to setae se. Setae $c 2$ long whip-like, 90-95 in length, situated in anterior angles of humeral shields. Setae $c 3$ lanceolate, rounded on apex, $16 \times 5$. Hysteronotal shield with anterior margin slightly convex, anterior angles almost rectangular, length 170 , width at anterior margin 77 , dorsal setae el situated posterior to openings $\mathrm{gl}$. Distance between prodorsal and hysteronotal shields 70 . Opisthosomal lobes elongated, separated by ovoid terminal cleft, without terminal membranes on apices of lobes (Fig. 3 a,c). Terminal cleft with entire interlobar membrane along margin, length of cleft 14 , width of cleft excluding membrane 28 , width of membranes in distal part of lobes 2.5-3. Transventral sclerite Yshaped, with long neck, length along median line 67 (Fig. 3b). Epiandrium encompassing genital apparatus, tips of epiandrium extending to level of setae $g$. Genital apparatus 21 in length, 11 in width. Transanal sclerite and adanal shields absent. Measurements: d2:e2 88, $d 2: g l$ 40, gl:el 24, h3:h3 24. Tarsus III with two apical teeth, all setae bristle-like, seta $r$ shorter than segment (Fig. 3d).

Female (paratype). Length of idiosoma 405, width of idiosoma 137, length of hysterosoma 264 (idiosomal size of another paratype $425 \times 127$ ). Prodorsal shield as in male, length 88 , width 67 , distance between setae $s e$ 55. Setae $c 2$ whip-like, $60-65$ in length, situated on striated tegument. Setae $c 3$ lanceolate, rounded on apex, $18 \times 5$. Arrangement of hysteronotal shields: central shield, pair of lateral opisthosomal shields and pygidial shield (Fig. 2c). Central shield large, ovoid, 144 in length, 84 in width. Distance between prodorsal shield and central shield 86. Lateral opisthosomal shields represented by heavily sclerotised plates of irregular form, length 28-32, width 38-40. Setae $e 2$ and $f 2$ on lateral opisthosomal shields, openings $g l$ on striated tegument at level of posterior margin of central shield. Measurements: d1:d2 38, d2:e2 110, d2:gl 53, gl: el 20, h3:h3 40. Epigynium 29 in length, 60 in width, with heavily sclerotised transversal bulk; posterior tips acute, almost parallel, not fused with epimerites IIIa (Fig. 2d).

Diagnosis. Pteroherpus cisticolae belongs to the benoiti species group (Faccini and Atyeo, 1981), the species of which are associated with the warblers of the genera Cisticola and Orthotomus (Sylviidae). Males of this group have the opisthosomal lobes widely separated, coxal fields III closed and the transanal sclerite absent. Of the two species formerly included into this group (Mironov 1992), the new species is most closely related to P. benoiti Faccini et Atyeo, 1981 by having the ovoid form of central shield in females (Fig. 2c). Females of $P$. cisticolae differ from that species by the shorter opisthosomal shields (28-32 in length). In females of $P$. benoiti these shields are represented by relatively narrow, oblique plates, 38-43 in length, 19-25 in width (Fig. 2e). Males of P. cisticolae are distinguished from $P$. benoiti by the narrow terminal cleft and narrow interlobar membranes (Fig. 3c). In $P$. benoiti the opisthosomal lobes are slightly divergent, width of terminal cleft is about 45-55, width of interlobar membranes in posterior parts of lobes is 7.2-8.0 (Fig. $3 e)$.

It is worth to note that males of $P$. cisticolae resemble more those of P. orthotomi Mironov, 1992 by the general form of opisthosomal lobes and terminal cleft. However, the new species differs from $P$. orthotomi by shorter terminal cleft and longer transventral sclerite. In males of $P$. orthotomi the length of terminal cleft is 27 32 and the length of transventral sclerite is 50-52.

$\mathrm{T} y \mathrm{p}$ e $\mathrm{h}$ o s $\mathrm{t}$ : Wing-snapped cisticola Cisticola ayresii Hartlaub, 1863 (Sylviidae).

T y p e 1 o c a 1 i t y : South Africa, Free State, Smiling Valley Farm.

Date of c o 11 e ction: 13.05.1989, A. Berruti coll.

T y p e m a te r i a 1 : Holotype male. Paratypes: 5 males, 2 females.

D e p o s ition of $\mathrm{m}$ at e ri a 1 : Holotype male and paratype female (No. 00287) - NMB; paratype 2 males (ZISP No. 4199) - ZISP; paratype 1 male and 1 female (PAU AVČR No. 1977) - PAU.

Remark. The study of additional materials of $P$. benoiti from the type host, Cisticola brachyptera (Sharpe, 1890), has shown that the length of setae $c 2$ was given incorrectly in the original description. The setae $c 2$ are not minute hair-like (Gaud 1964, fig. 3b), but they are actually as long as in P. cisticolae, 90-95 in males and 60-65 in females.

\section{Genus Pteronyssoides Hull, 1931}

Up to date, the genus has included 12 species (Faccini and Atyeo 1981, Mironov 1989). Mites of this genus have been known from birds of different passerine families distributed in the Old World (Dicruridae, Estrildidae, Fringillidae, Motacillidae, Nectariniidae, Paridae, Ploceidae and Pycnonotidae). The majority of species belongs to the nominal subgenus, while a group of four species associated with the Pycnonotidae and Timaliidae is separated into the subgenus Holonyssoides (Mironov 1993).

\section{Pteronyssoides (Pteronyssoides) promeropis sp. $\mathrm{n}$.} Figs. 4, 5 a,b

Male (holotype). Length of idiosoma 322, width of idiosoma 200, length of hysterosoma 200 (idiosomal size of 5 paratypes: $320-347 \times 200-215$ ). Prodorsal shield: length 92 , width 86 , distance between bases of 

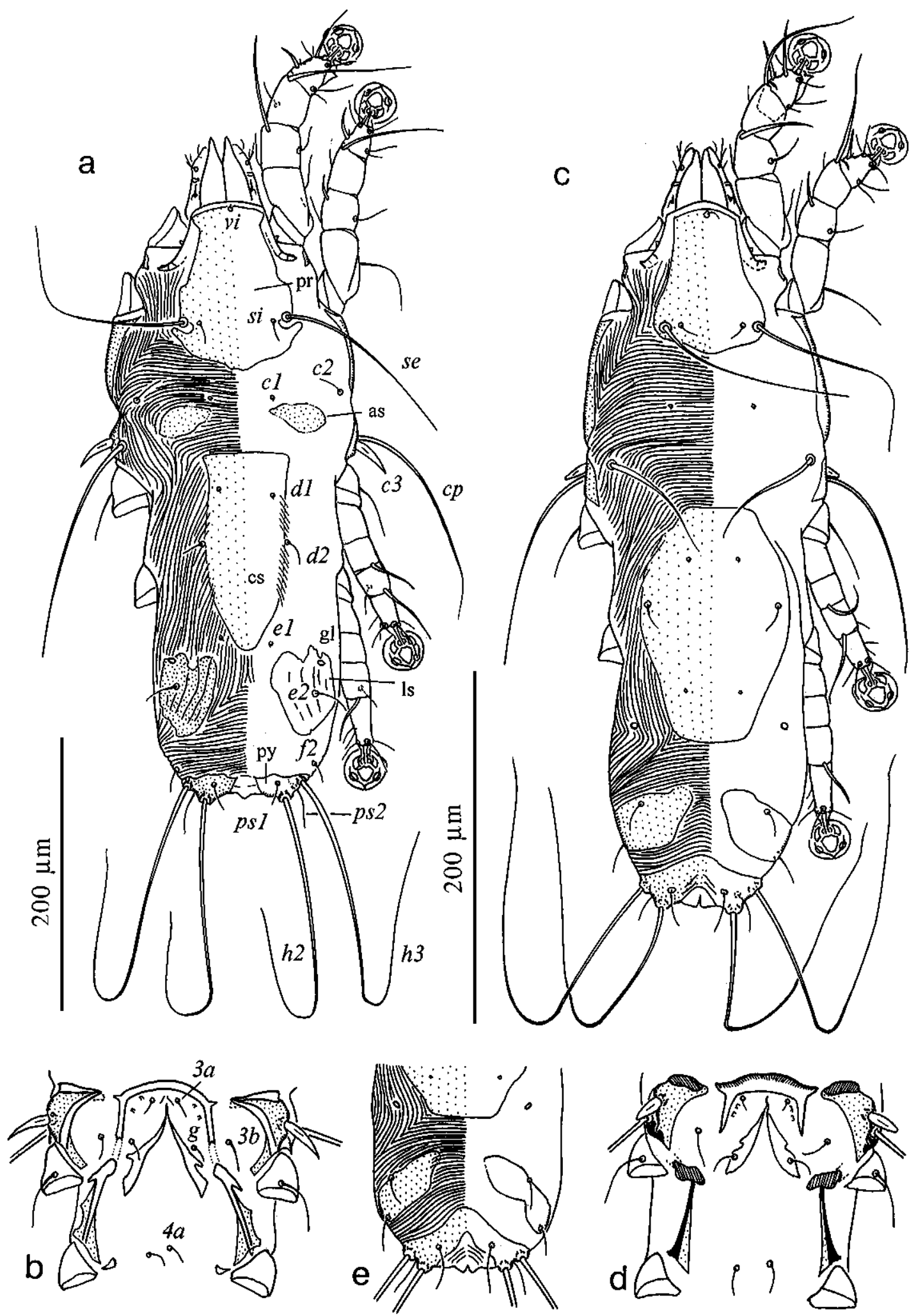

Fig. 2. Females of the genus Pteroherpus. a - Pteroherpus africanus sp. n., dorsal view; $\mathbf{b}-$ same, epigynium and coxal fields III, IV; c - Pteroherpus cisticolae sp. n., dorsal view; d - same, epigynium and coxal fields III, IV; e - Pteroherpus benoiti Faccini et Atyeo, 1981, dorsal view of opisthosoma. as - anterior hysteronotal shield; cs - central shield; ls - lateral opisthosomal shield; pr - prodorsal shield; py - pygidial shield. 


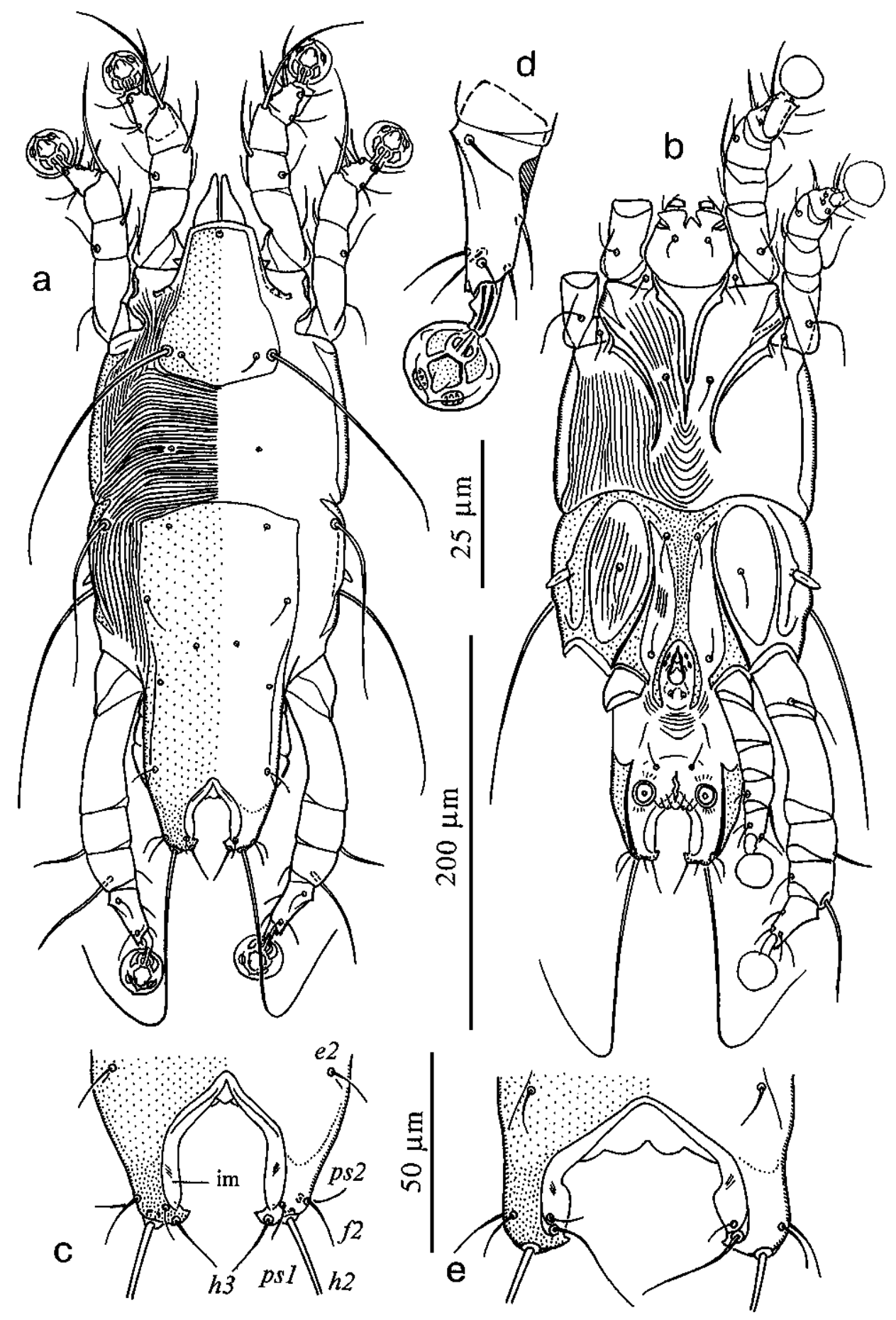

Fig. 3. Males of the genus Pteroherpus. a - Pteroherpus cisticolae sp. n., dorsal view; b-same, ventral view; c - same, dorsal view of opisthosoma; d - same, tarsus III, dorsal view; e - Pteroherpus benoiti Faccini et Atyeo, 1981, dorsal view of opisthosoma. im - interlobar membrane.

setae se 75 , posterior margin slightly convex, lateral margins with small incision posterior to bases of setae se. Setae $c 2$ short hair-like, about 15 in length, situated medial to anterior angles of humeral shields. Setae $c 3$ narrow lanceolate, with hair-like apical part, 55-57 in length, 2.5 in width (Fig. 4a). Hysteronotal shield: length 168 , width at anterior margin 132, anterior an-gles acute, anterior margin deeply concave, sinuous in medial part. Dorsal setae el situated posterior to open-ings $\mathrm{gl}$. Distance between prodorsal and hysteronotal shields 

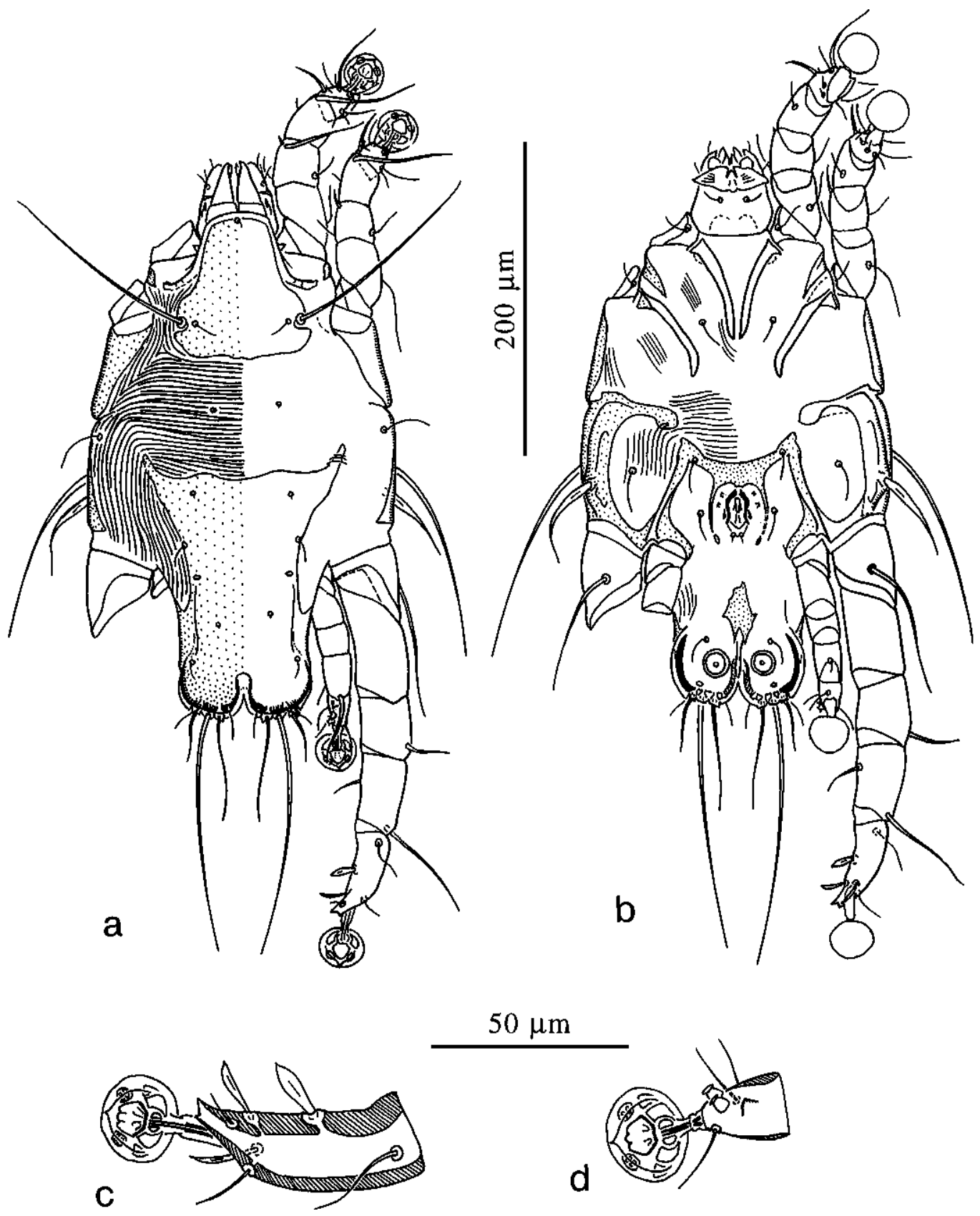

Fig. 4. Pteronyssoides promeropis sp. n., male. a-dorsal view; $\mathbf{b}$ - ventral view; $\mathbf{c}$ - tarsus III, dorsal view; $\mathbf{d}$ - tarsus IV, dorsal view.

along medial line 77. Opisthosomal lobes short, bluntly rounded. Terminal cleft small, U-shaped, fused with supranal concavity, margins of cleft with narrow membrane, length of cleft including concavity 24 , width 8 , length of incision in membrane 15 . Measurements d2:e2 74, d2:gl 20, gl:el 24-31, h3:h3 31. Transventral sclerite 12 in length along median line. Epiandrium completely encompassing genital apparatus, tips of epiandrium thin, extending beyond level of setae $g$ (Fig. 4b). Genital apparatus 22 in length, 14 in width. Setae $4 a$ at midlevel of genital apparatus. Transanal sclerite absent, adanal shield represented by longitudinal sclerite of irregular form, adanal apodemes bow-like. Diameter of anal discs 14. Tarsus III with two apical teeth, setae $w$ thick lanceolate, setae $s, f$ with narrow lanceolate apices, seta $r$ hair-like, shorter than segment (Fig. 4c).

Female (paratype). Length of idiosoma 410, width of idiosoma 200, length of hysterosoma 278 (idiosomal size in 5 paratypes: $395-457 \times 185-215)$. Prodorsal shield: length 89 , width 96 , lateral margin with incision 

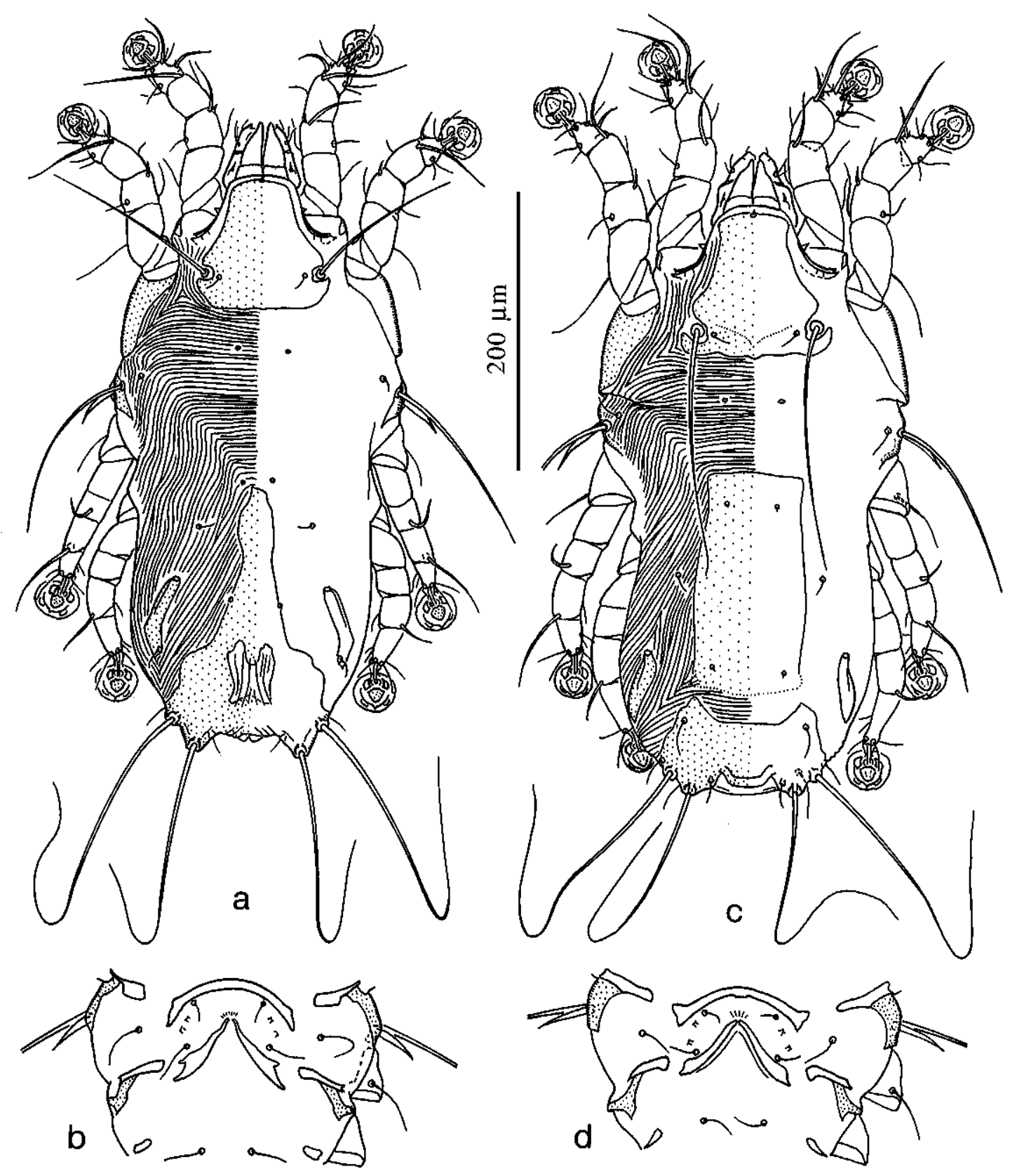

Fig. 5. Females of the family Pteronyssidae. a - Pteronyssoides promeropis sp. n., dorsal view; $\mathbf{b}$ - same, epigynium and coxal fields III, IV; c-Sturnotrogus creatophorae sp. n., dorsal view; d - same, epigynium and coxal fields III, IV.

around setae se, distance between these setae 82 . Setae $c 2$ short hair-like, 10 in length, situated on striated tegument. Setae $c 3$ lanceolate, with acute apex, $29 \times 4$. Arrangement of dorsal hysteronotal shields: large medial hysteronotal shield covering pygidial part of opistho-soma and medial area of hysterosoma, pair of lateral opisthosomal shields (Fig. 5a). Medial hysteronotal shield 187 in length, 108 in width at level of setae $h 3$, with triangular anterior part extending to level of trochanters IV, posterior part of this shield with $\mathrm{H}$-shaped or rectangular lacuna, setae $d 1, d 2$ situated off shield, setae $e 1$ on lateral margins of shield. Lateral opisthosomal shields narrow lanceolate, openings $g l$ situated in their anterior ends, setae $e 2$ disposed on their posterior ends. Measurements: d1:d2 31, d2:e2 96, $d 2: g l$ 48, gl:el 9.5, h3:h3 77. Epigynium bow-like, length 32 , width 86 , tips not fused with epimerites IIIa (Fig. 5b). 

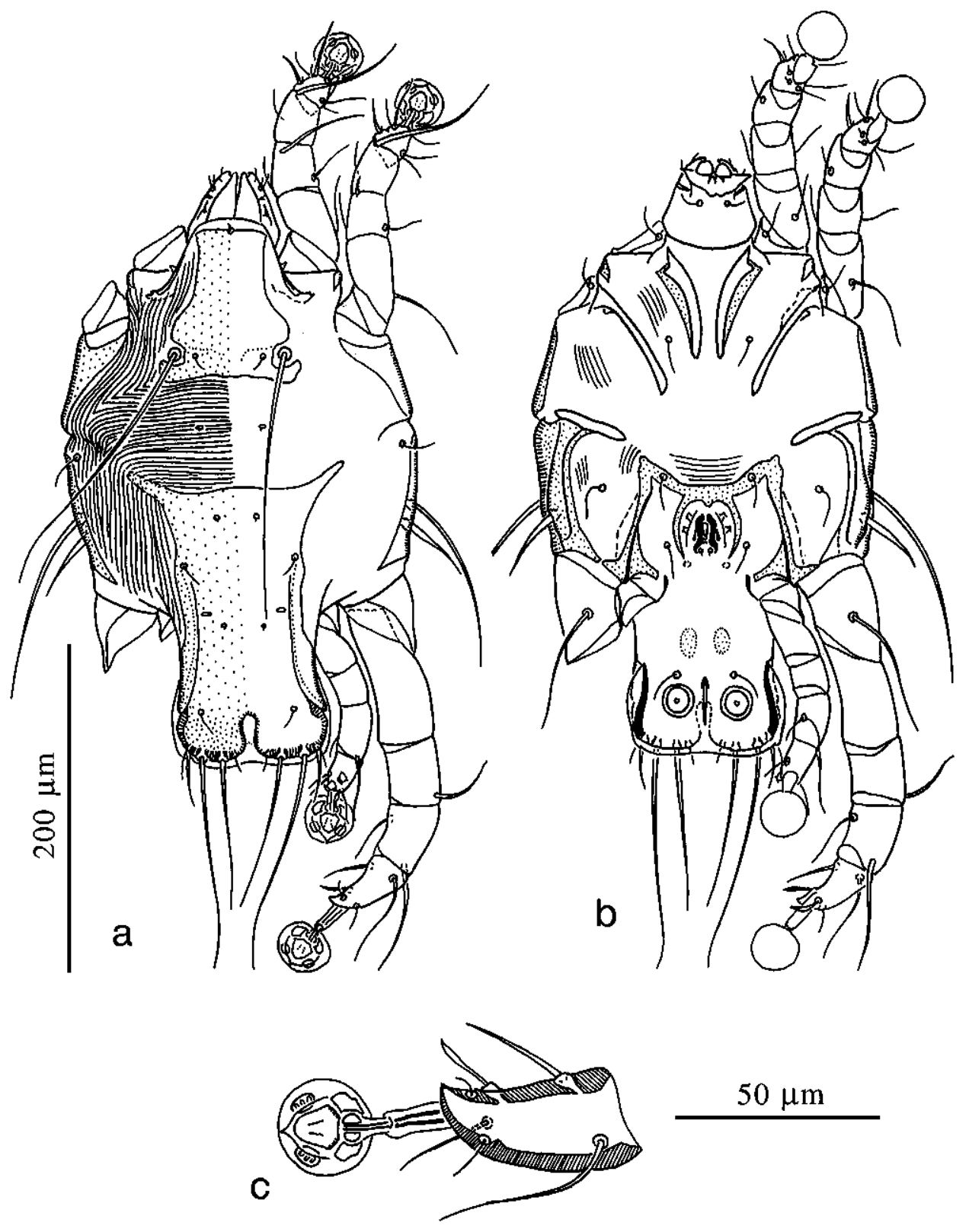

Fig. 6. Sturnotrogus creatophorae sp. n., male. a - dorsal view; b - ventral view; $\mathbf{c}$ - tarsus III, dorsal view.

Diagnosis. The structure of the dorsal hysteronotal shields in females (Fig. 5a) is unique among currently known species of the genus Pteronyssoides and most comparable with that in Pteronyssoides garioui Gaud et Mouchet, 1959. In females of $P$. promeropis, the pygidial shield and central shield are fused into single medial hysteronotal shield covering the posterior part of opisthosoma and medial part of hysterosoma. In females of $P$. garioui, sclerites in the central part of hysterosoma are absent, and the pygidial shield extends to the level of setae el only; the lateral opisthosomal shields are absent. Males of $P$. promeropis can easily be differentiated from males of $P$. garioui and all other species of the genus Pteronyssoides by the lanceolate setae $w$ on tarsus III (Fig. 4c).

T y p e h o s t : Gurney's sugarbird Promerops gurneyi Verreaux, 1871 (Promeropidae).

T y p e 1 o c a 1 it y: South Africa, Free State, Waterual.

D a t e of c o 11 e c t i o n : 24.03.1989, D.H. de Stewart coll.

T y p e m a t e r i a 1: Holotype male. Paratypes: 5 males, 6 females.

De p o s it i o n of materia 1 : Holotype male, paratype male and 2 females (No. 00233) - NMB; paratype 2 males and 2 females (ZISP No. 4201) - ZISP; paratype male and 2 females (PAU AVČR No. 1978) - PAU. 


\section{Genus Sturnotrogus Mironov, 1989}

Up to date the genus Sturnotrogus has included 6 species (Mironov 1989, 1993). Four of them are associated with different species of starlings (Sturnidae) and two species occur on flycatchers of the genus Rhipidura (Muscicapidae). In the recent monograph on the feather mites of the World by Gaud and Atyeo (1996) this genus is considered a subgenus of Scutulanyssus Mironov, 1985.

Sturnotrogus creatophorae sp. n. Figs. 5 c,d, 6 a-c

Male (holotype). Length of idiosoma 337, width of idiosoma 220, length of hysterosoma 210 (idiosomal size of 3 paratypes: total length $315-335 \times 200-220$ ). Prodorsal shield: length 96, width 91, distance between bases of setae se 72, posterior margin almost straight, lateral margins with little incisions around setae se. Setae $c 2$ short hair-like, about 26 in length, situated slightly medial to anterior angles of humeral shields. Setae $c 3$ lanceolate, with acute apex, $40 \times 3$. Hysteronotal shield: length 187 , width at anterior margin 132 , anterior angles acute, anterior margin concave, lateral margins without incisions. Dorsal setae el situated posterior to level of openings $g l$. Distance between prodorsal and hysteronotal shields along medial line 57. Opisthosomal lobes short, with blunt posterior ends, opisthosoma with almost straight posterior margin between setae $f 2$, with narrow entire membrane along margin. Terminal cleft small, fused with supranal concavity, length including concavity 24 . Width of opisthosoma at level of setae $f 2$ about 96. Measurements: d2:d2 100, d2:gl 38, el:gl 7.5, h3:h3 41. Transventral sclerite 9.5 in length along median line. Epiandrium encompassing genital apparatus, tips extending to level of setae $g$ (Fig. 6b). Genital apparatus 24 in length, 12 in width. Transanal sclerite absent, adanal shields represented by pair of little ovoid sclerites anterior to setae ps3. Diameter of anal discs 17. Tarsus III with claw-like apex, seta $s$ with narrow lanceolate apices, seta $r 1.5$ times longer than segment (Fig. 6c).

Female (paratype). Length of idiosoma 415, width of idiosoma 220, length of hysterosoma 283 (idiosomal size in 3 paratypes: $410-420 \times 205-234)$. Prodorsal shield as in male, length 103 , width 108 , distance between setae se 86 . Setae $c 2$ short hair-like, 25 in length, situated on striated tegument. Setae c3 narrow lanceolate, 36 in length, 2.5 in width. Arrangement of dorsal hysteronotal shields: central shield, pygidial shield, pair of lateral opisthosomal shields (Fig. 5c). Central shield almost rectangular, 115 in length, 75 in width, anterior angles not extending, setae $e 2$ situated off shield. Distance between prodorsal and central shields 74. Pygidial shield as large plate with deeply concave anterior margin, 55 in length, 108 in width, separated from central shield by 7.5. Lateral opisthosomal shields lanceolate, with $g l$ openings in anterior ends. Setae $e 1$ situated posterior to level of $g l$ openings. Measurements: $d 1: d 2$ 46-48, d2:e2 108, d2:gl 53, gl:e1 12 , h3:h3 77. Epigynium bow-like, with slightly enlarged tips, length 29, width 84 (Fig. 5d).

Diagnosis. Sturnotrogus creatophorae belongs to the truncatus species group, the females of which are characterised by separated central and pygidial shields (Fig. 5c). This group, including the new species, nocsists of four species associated with the starlings, Sturnidae. Within the truncatus group, the new species is most closely related to $S$. pastoris (Mironov, 1987), described from the rose-coloured starling Sturnus roseus (L.). Males of $S$. creatophorae differ from males of that species by the greater length of idiosoma and by absence of incisions in lateral margins of hysteronotal shield. In males of $S$. pastoris, the idiosomal length varies within 335-360 and the lateral margins of the hysteronotal shield have small incisions at the level of setae $c p$. Females of the new species are distinguished from $S$. pastoris by rectangular form of central shield and concave anterior margin of pygidial shield. In females of S. pastoris, the central shield is with extending anterior angles and pygidial shield with straight anterior margin.

$\mathrm{T}$ y $\mathrm{p}$ e $\mathrm{h}$ o s t : Wattled starling Creatophora cinerea (Menschen, 1787) (Sturnidae).

T y p e 1 o c a 1 it y: South Africa, Free State, Pelissier.

D a t e of c o 11 e ct i o n :20.05.1989, R.A. Earle coll.

$\mathrm{T}$ y p e $\mathrm{m}$ a t e r i a 1 : Holotype male. Paratypes: 3 males, 4 females.

D e p o s it i o n of mat e r i a 1: Holotype male and paratype female (No. 00260) - NMB; paratype male and female (ZISP No. 4205) - ZISP; paratype 2 males, 2 females (PAU AVČR No. 1979, 1980) - PAU.

Acknowledgements. The authors wish to thank Dr. R. Nuttall, head of the Ornithological Department of the National Mu-seum of Bloemfontein (Free State, South Africa), for a loan of the feather mite materials used in the present study. The taxonomic part of the present work was supported by the Russian Fund for Basic Researches (Grant No. 00-04-49323). 


\section{REFERENCES}

ATYEO W.T., FACCINI J.L.H., GAUD J. 1987: The feather mite genus Ramphastobius Gaud (Avenzoariidae) associated with Neotropical Piciformes (Aves). Parazitol. Sb. 34: 150-168. (In Russian with English summary.)

ATYEO W.T., GAUD J. 1966: The chaetotaxy of sarcoptiform feather mites. J. Kans. Entomol. Soc. 39: 337-346.

FACCINI J.L.H., ATYEO W.T. 1981: Generic revisions of the Pteronyssinae and Hyonyssinae (Analgoidea: Avenzoariidae). Proc. Acad. Nat. Sci. Phila. 133: 20-72.

GAUD J. 1952: Sarcoptides plumicoles des oiseaux de Madagascar. Mem. Inst. Sci. Madagascar, Ser. A, Biol. Anim. 7: 81-107.

GAUD J. 1964: Mission de zoologie medicale au Maniema (Congo, Leopoldville) (P.L.G. Benoit, 1959). 8. Acariens plumicoles (Analgesoidea). Ann. Mus. R. Afr. Cent. Ser. in-8, Sci. Zool. 132: 119-130.

GAUD J. 1988: Acariens sarcoptiformes plumicoles parasites des Piciformes d'Afrique. I. Parasites des Indicatoridae. Rev. Zool. Afr. 102: 411-428.

GAUD J. 1989: Acariens sarcoptiformes plumicoles parasites des Piciformes d'Afrique. II. Acariens de la sous-famille Hyonyssinae (Analgoidea, Avenzoariidae). Rev. Zool. Afr. 103: 229-242.

GAUD J. 1990a: Acariens sarcoptiformes plumicoles parasites des Piciformes d'Afrique. III. Parasites des Capitonidae et des Picidae - Acariens de la sous-famille Pteronyssinae Genre Anephippius. J. Afr. Zool. 104: 229-239.

GAUD J. 1990b: Acariens sarcoptiformes plumicoles parasites des Piciformes d'Afrique. IV. Parasites des Capitonidae et des Picidae - Acariens de la sous-famille Pteronyssinae - Genre Conomerus. J. Afr. Zool. 104: 313333.

GAUD J. 1991: Acariens sarcoptiformes plumicoles parasites des Piciformes d'Afrique. V. Acariens des genres Pegopteronyssus et Pteronyssus. J. Afr. Zool. 105: 113-124.

GAUD J., ATYEO W.T. 1996: Feather mites of the World (Acarina, Astigmata). The supraspecific taxa. Ann. Mus. R. Afr. Cent., Sci. Zool. 277. Part I: 1-193, Part II: 1-436.

GAUD J., CORPUZ-RAROS L. 1985: A new feather mite genus, Zygepigynia (Pteronyssinae, Avenzoariidae), associated with Chrysocolaptes lucidus from Philippines. Philipp. Entomol. 6: 392-397.

GAUD J., MOUCHET J. 1959: Acariens plumicoles des oiseaux du Cameroun. V. Pterolichidae. Ann. Parasitol. Hum. Comp. 34: 493-545.

GAUD J., PETITOT P. 1948: Sarcoptides plumicoles des oiseaux du Maroc. Ann. Parasitol. Hum. Comp. 23: 337347.

GRIFFITHS D.A., ATYEO W.T., NORTON R.A., LYNCH C.A. 1990: The idiosomal chaetotaxy of astigmatid mites. J. Zool. (Lond.) 220: 1-32.

HOWARD R., MOORE, A.A. 1991: A Complete Checklist of the Birds of the World. Second Edition. Academic Press, London, $732 \mathrm{pp}$.

MIRONOV S.V. 1989: A review of the feather mites of the subfamily Pteronyssinae from the USSR (Analgoidea, Avenzoariidae). Parazitol. Sb. 35: 96-124. (In Russian with English summary.)

MIRONOV S.V. 1992: Five new species of the feather mite genus Pteroherpus Gaud (Analgoidea: Avenzoariidae) from passerine birds of Vietnam. Int. J. Acarol. 18: 1-12.

MIRONOV S.V. 1993: New taxa of the feather mite subfamily Pteronyssinae (Analgoidea: Avenzoariidae) from passerine birds of Vietnam. Parazitologiya 27: 410-418. (In Russian with English summary.)

MIRONOV S.V., KOPIJ G. 1996a: New feather mite species (Acarina: Analgoidea) from some starlings (Passeriformes: Sturnidae) of South Africa. J. Afr. Zool., 110: 257-269.

MIRONOV S.V., KOPIJ G. 1996b: Three new species of the feather mite family Proctophyllodidae (Acarina: Analgoidea) from some South African passerines (Aves: Passeriformes). Acarina (Moscow) 4: 27-33.

MIRONOV S.V., KOPIJ G. 1997: New feather mite species of the subfamily Pterodectinae (Analgoidea: Proctophyllodidae) from some passerines (Aves: Passeriformes) of South Africa. J. Afr. Zool. 111: 449-463.

MIRONOV S.V., KOPIJ G. 2000: A new feather mite species of the genus Metapteronyssus Gaud, 1981 (Analgoidea: Pteronyssidae). Genus (Wroclaw) 11: 99-103. 